\title{
Hubungan Posisi Menunduk saat Menggunakan Telepon Seluler dengan Nyeri Tengkuk
}

\author{
Ramadhani Dinda Salsalina Depari*, Aldy Safruddin Rambe \\ Departemen Neurologi, Fakultas Kedokteran, Universitas Sumatera Utara, Medan \\ *Correspondence: mecca201216@gmail.com
}

\begin{abstract}
ABSTRAK
Latar Belakang: Nyeri tengkuk adalah rasa nyeri yang meliputi kelainan saraf, tendon, otot dan ligamen di sekitar leher. Salah satu penyebab dari nyeri tengkuk adalah posisi tubuh yang salah sehingga membuat leher berada dalam posisi tertentu dalam jangka waktu yang lama. Pada penggunaan telepon seluler akan terjadi proses perubahan posisi leher, yang mana posisi kepala akan menunduk untuk melihat ke arah layar telepon seluler dan dipertahankan dalam waktu yang relatif lama, sehingga menimbulkan masalah otot yang apabila dibiarkan dapat menjadi nyeri otot kronis. Tujuan: Untuk mengetahui hubungan posisi menunduk saat menggunakan telepon seluler dengan nyeri tengkuk. Metode: Penelitian ini merupakan penelitian analitik-observasional dengan desain cross-sectional. Pengambilan sampel dilakukan dengan teknik simple random sampling. Hasil pengukuran akan dianalisis menggunakan uji chi-square. Nilai $\mathrm{p}<0,05$ dianggap signifikan. Hasil: Terdapat hubungan antara posisi menunduk saat menggunakan telepon seluler terhadap nyeri tengkuk dengan nilai $\mathrm{P}=0,045$. Pada uji hubungan lainnya tidak ada hubungan antara durasi penggunaan telepon seluler terhadap nyeri tengkuk baik dalam sekali penggunaan $(\mathrm{P}=0,509)$ maupun dalam sehari penggunaan $(\mathrm{P}=0,729)$. Kesimpulan: Terdapat hubungan yang signifikan antara posisi menunduk saat menggunakan telepon seluler dengan nyeri tengkuk.
\end{abstract}

\section{Kata Kunci: nyeri tengkuk, telepon seluler, posisi menunduk}

\section{ABSTRACT}

Background: Neck pain is pain that includes disorders of the nerves, tendons, muscles and ligaments around the neck. One of the causes of neck pain is the wrong position of the body which causes the neck in a certain position for a long time. In the use of cell phones there will be a process of changing the position of the neck, the position of the head will be bow to look at the cell phone screen and maintained for a long time, causing muscle problems which, if left unchecked, can become chronic muscle pain. Objectives: To find out relationship between the bow position when using a cell phone and neck pain. Methods: This study is an analytic-observational study with a cross-sectional design. The sampling technique used simple random sampling technique. The data will be analyze using chisquare statistical test. In which the p-value < 0.05 is significant. Results: There is a relationship between the bow position when using a cell phone to neck pain with p-value 0.045. On the other test, there is no relationship between the duration of cell phone use and neck pain, both in one use ( $p=$ $0.509)$ and in a day $(p=0.729)$. Conclusion: There is a significant relationship between the bow position when using a cell phone and neck pain.

Keywords: neck pain, cell phone, bowing position

Received [22 Jan 2021] | Revised [4 May 2021] | Accepted [21 Aug 2021] 


\section{PENDAHULUAN}

Penggunaan telepon seluler yang tidak terkontrol dapat menimbulkan efek negatif dari telepon seluler itu sendiri. ${ }^{[1]}$ Beberapa masalah yang muncul dalam penggunaan telepon seluler antara lain efek kecanduan, anti sosial, perubahan mood dan muncul permasalahan kesehatan seperti nyeri pada leher khususnya bagian tengkuk dan pergelangan tangan. ${ }^{[2]}$ Permasalahan kesehatan ini erat hubungannya dengan posisi tubuh seseorang saat bermain telepon seluler baik dari posisi duduk maupun posisi leher orang tersebut. Pada penggunaan telepon seluler akan terjadi proses perubahan posisi leher, yang mana posisi kepala akan menunduk untuk melihat ke arah layar telepon seluler dan dipertahankan dalam waktu yang relatif lama sehingga menimbulkan masalah otot dan apabila dibiarkan dapat menjadi nyeri otot kronis. ${ }^{[3]}$

Nyeri tengkuk merupakan masalah muskuloskeletal di leher yang terjadi pada masyarakat modern. Nyeri tengkuk adalah rasa nyeri yang meliputi kelainan saraf, tendon, otot dan ligamen di sekitar leher. Salah satu penyebab dari nyeri tengkuk adalah posisi tubuh yang salah sehingga membuat leher berada dalam posisi tertentu dalam jangka waktu yang lama. ${ }^{[4]}$ Sebuah studi populasi menunjukkan bahwa, $20-65 \%$ wanita dan $15-40 \%$ pria dilaporkan pernah mengalami gejala-gejala nyeri tengkuk dan bahu dalam hidupnya. ${ }^{[5]}$ Selama 1 tahun, prevalensi nyeri muskuloskeletal di daerah leher pada pekerja besarnya berkisar antara 6-76\% dan wanita ternyata juga lebih tinggi dibandingkan pria. ${ }^{[6]}$ Di Indonesia, setiap tahun sekitar $16,6 \%$ populasi orang dewasa mengeluhkan rasa tidak enak di leher, dengan $0,6 \%$ mengalami nyeri leher yang memberat. ${ }^{[7]}$ Selain memberikan nyeri pada bagian leher belakang, nyeri tengkuk juga menurunkan gerakan sendi leher dan aktivitas fungsional leher sehingga dapat mempengaruhi kegiatan penderita. Nyeri tengkuk ini akan terjadi jika dilakukan gerakan yang berulang pada penggunaan telepon seluler. ${ }^{[8]}$

\section{METODE}

Penelitian ini merupakan penelitian studi analitik-observasional dengan rancangan cross sectional untuk mengetahui hubungan posisi menunduk saat menggunakan telepon seluler terhadap nyeri tengkuk. Penelitian ini dilakukan secara online melalui google form yang dapat diakses pada link https://bit.ly/3hUeqPO yang dikirim melalui media sosial dengan waktu pengumpulan data penelitian dilaksanakan pada bulan September-Oktober 2020. Populasi terjangkau pada penelitian ini merupakan mahasiswa FK USU angkatan 2017 dengan teknik pengambilan sampel menggunakan simple random sampling dan jumlah sampel sebesar 63 orang. ${ }^{[9]}$

Kriteria inklusi pada penelitian ini adalah Mahasiswa aktif FK USU angkatan 2018, bersedia menjadi subjek penelitian, menggunakan telepon seluler dalam kesehariannya. Kriteria eklusi pada penelitian ini adalah memiliki riwayat trauma leher yang mengakibatkan defisit neurologis, dan memiliki riwayat penyakit tulang belakang servikal seperti cervical myelopathy seperti penekanan pada medula spinalis, infeksi pada servikal, neoplasma, rematik (ankylosing spondylitis, spondyloarthropathies dan rheumatoid arthritis), cervical dystonia. Untuk memenuhi kriteria inklusi dan tidak termasuk ke dalam kriteria eksklusi, responden diarahkan untuk membaca penjelasan peneliti yang ada di google form. Setelah memenuhi semua kriteria, responden diarahkan untuk mengisi kuesioner online pada link yang telah diberikan, data yang telah terkumpul akan dianalisa menggunakan SPSS dengan uji chi-square dengan nilai $\mathrm{p}$ dikategorikan signifikan apabila nilainya $<0,05$. 
HASIL

Tabel 1. Karakteristik responden

\begin{tabular}{lcc}
\hline Karakteristik & n & \% \\
\hline Jenis Kelamin & & \\
Laki-laki & 11 & 17,5 \\
Perempuan & 52 & 82,5 \\
Umur (tahun) & & \\
$15-20$ & 58 & 92,1 \\
$21-25$ & 5 & 7,9
\end{tabular}

Berdasarkan Tabel 1 penelitian ini terdiri dari 63 responden dengan kelompok terbesar berdasarkan jenis kelaminnya adalah kelompok perempuan yaitu sebanyak 52 mahasiswa (82,5\%), sedangkan pada kelompok laki-laki terdapat 11 mahasiswa $(17,5 \%)$. Berdasarkan usia didapat data bahwa kelompok terbesar adalah pada usia antara

15-20 yaitu sebanyak 58 mahasiswa $(92,1 \%)$ dan yang berusia 21-25 tahun sebanyak 5 mahasiswa $(7,9 \%)$.

Tabel 2. Distribusi frekuensi nyeri tengkuk

\begin{tabular}{lcc}
\hline Karakteristik & n & \% \\
\hline Nyeri tengkuk & 39 & 61,9 \\
$\quad$ Ya & 24 & 38,1 \\
$\quad$ Tidak & & \\
$\begin{array}{l}\text { Skala nyeri tengkuk } \\
\text { dalam satu minggu } \\
\text { terakhir }\end{array}$ & & \\
$\quad$ Nyeri ringan & 30 & 47,6 \\
$\quad$ Nyeri sedang & 8 & 12,7 \\
$\quad$ Nyeri berat & 1 & 1,6 \\
Penyebaran nyeri & & \\
tengkuk & & \\
$\quad$ Ya & 5 & 7,9 \\
$\quad$ Tidak & 58 & 92,1 \\
Lokasi penyebaran & & \\
$\quad$ Bahu & 1 & 1,6 \\
Punggung & 3 & 4,8 \\
Tangan & 1 & 1,6
\end{tabular}

Berdasarkan Tabel 2 dapat dilihat bahwa prevalensi nyeri tengkuk pada 1 minggu terakhir pada mahasiswa FK USU angkatan 2018 pada tahun 2020 adalah 39 kasus $(61,9 \%)$ dengan 30 mahasiswa $(47,6 \%)$ mengalami nyeri tengkuk ringan, 8 mahasiswa $(12,7 \%)$ mengalami nyeri tengkuk sedang dan 1 mahasiswa $(1,6 \%)$ mengalami nyeri tengkuk berat. Mahasiswa yang mengalami penyebaran nyeri tengkuk sebanyak 5 mahasiswa (7,9\%) dengan lokasi penyebaran ke bahu sebanyak 1 mahasiswa $(1,6 \%)$, ke daerah punggung sebanyak 3 mahasiswa $(4,8 \%)$ dan ke tangan sebanyak 1 mahasiswa $(1,6 \%)$.

Tabel 3. Distribusi frekuensi penggunaan telepon seluler

\begin{tabular}{lcc}
\hline Karakteristik & n & \% \\
\hline $\begin{array}{l}\text { Durasi pemakaian } \\
\text { telepon seluler dalam } \\
\text { satu kali pemakaian } \\
\quad>30 \text { menit }\end{array}$ & & \\
$\quad<30$ menit & 52 & 82,5 \\
$\quad \begin{array}{l}\text { Durasi pemakaian } \\
\text { telepon seluler dalam }\end{array}$ & 11 & 17,5 \\
$\quad$ satu hari & & \\
$\quad>3$ jam & 53 & 84,1 \\
$\quad<3$ jam & 10 & 15,9 \\
$\begin{array}{l}\text { Memiliki telepon seluler } \\
\text { lebih dari satu }\end{array}$ & & \\
$\quad$ Ya & & \\
$\quad$ Tidak & 48 & 23,8 \\
Posisi leher menunduk & 15 & 76,2
\end{tabular}

Posisi leher menunduk saat menggunakan telepon seluler $\begin{array}{lll}\text { Ya } & 55 & 87,3\end{array}$ $\begin{array}{lll}\text { Tidak } & 8 & 12,7\end{array}$

Berdasarkan Tabel 3 diperoleh hasil bahwa mahasiswa yang menggunakan telepon seluler dalam satu kali pemakaian dengan durasi >30 menit lebih banyak yaitu sebanyak 52 mahasiswa, sedangkan dengan durasi <30 menit sebanyak 11 mahasiswa. Berdasarkan durasi pemakaian telepon seluler dalam satu hari dengan durasi $>3$ jam lebih banyak yaitu sebanyak 53 mahasiswa, sedangkan dengan durasi $<3$ jam yaitu 10 orang. Dari data yang sudah dikumpulkan didapat bahwa yang memiliki telepon seluler lebih dari satu yaitu sebanyak 15 mahasiswa dan 48 mahasiswa lainnya hanya memiliki satu telepon seluler dengan 55 mahasiswa menunduk saat menggunakan telepon seluler dan 8 mahasiswa tidak menunduk saat menggunakan telepon seluler. 
Tabel 4. Hubungan posisi menunduk saat menggunakan telepon seluler dengan kejadian nyeri tengkuk.

\begin{tabular}{ccccccc}
\hline & & \multicolumn{2}{c}{ Nyeri Tengkuk } & & Total & p \\
\cline { 3 - 4 } & & Tidak & Ya & & & value \\
\hline Posisi & Ya & 18 & 37 & 55 & \\
leher menunduk & Tidak & 6 & 2 & 8 & 0,045 \\
Total & & 24 & 39 & 63 & \\
\hline
\end{tabular}

\section{PEMBAHASAN}

Hasil penelitian menunjukkan bahwa selama menggunakan telepon seluler, postur tubuh responden berada dalam posisi tidak ergonomis yaitu leher menunduk saat menggunakan telepon seluler yaitu sebanyak 55 responden $(87,3 \%)$. Postur yang tidak ergonomis ini menjadi salah satu penyebab munculnya keluhan muskuloskeletal. ${ }^{[10]}$ Uji analisis statistik menggunakan uji fisher exact didapatkan $\mathrm{p}$ value sebesar 0,045 . $\mathrm{P}$ value $<0,05$ ini mengartikan bahwa hipotesis kerja pada penelitian ini diterima, yaitu terdapat hubungan yang signifikan antara posisi menunduk saat menggunakan telepon seluler dengan nyeri tengkuk pada mahasiswa Fakultas Kedokteran Universitas Sumatera Utara angkatan 2018. Nyeri tengkuk merupakan respon diluar kesadaran yang dilakukan oleh otot. Otot berkontraksi, sehingga menjadi keras kaku dan nyeri. Rasa nyeri yang sering dikeluhkan biasanya berupa pegal dan jika berlangsung lama dapat menjalar ke lengan, tangan, dan kepala bagian belakang. ${ }^{[4]}$ Hal ini disebabkan karena penggunaan telepon seluler dengan posisi leher yang tidak ergonomis (posisi leher statis dalam waktu yang lama) atau oleh gerakan yang berulang dan tekanan pada otot leher. ${ }^{[11]}$ Nyeri tengkuk juga dapat terjadi pada seseorang yang menghabiskan sebagian besar waktunya bekerja dengan duduk dalam posisi forward head posture. $^{[12]}$ Posisi menunduk yang dipertahankan dalam waktu lama ini besar kemungkinan akan menimbulkan masalah pada daerah leher. Daerah leher yang paling sering mengalami posisi ini adalah pada leher bagian bawah yang berada di dekat bahu. Vertebra C5 dan C6 akan tertarik ke arah depan mengikuti tarikan gravitasi kepala sehingga menyebabkan postur tubuh menjadi forward head posture. ${ }^{[13]}$ Nyeri tengkuk yang terjadi akibat posisi yang tidak ergonomis ini tidak hanya terjadi saat menggunakan telepon seluler saja, namun juga terjadi pada beberapa kegiatan yang melibatkan peran leher dalam melakukan suatu kegiatan. Hal ini sesuai dengan penelitian yang dilakukan oleh Wijayati E.W., tentang risiko postur kerja terhadap keluhan subyektif nyeri leher pada pekerja industri kerajinan kulit, dengan melakukan uji statistik chi-square didapatkan hasil yang signifikan yaitu $\mathrm{p}$ value sebesar 0,006 $(p<0,05) .^{[14]}$ Penelitian lainnya yang dilakukan oleh Belayana et al., tentang faktor waktu kerja, waktu istirahat dan sikap kerja terhadap keluhan nyeri tengkuk pada pengrajin ukiran kayu, dengan melakukan uji statistik chi-square didapatkan nilai $\mathrm{p}$ value sebesar 0,000 $(\mathrm{p}<0,05)$, ini berarti Ho ditolak atau $\mathrm{Ha}$ diterima. ${ }^{[15]}$

\section{KESIMPULAN}

Terdapat hubungan antara posisi menunduk saat menggunakan telepon seluler dengan nyeri tengkuk.

\section{SARAN}

Penelitian ini masih dapat diteliti lebih lanjut dengan menggunakan metode 
penelitian eksperimental, sehingga diperoleh hasil dari sudut pandang yang berbeda.

\section{DAFTAR PUSTAKA}

[1] Lee, W-J. dan Shin, S. (2016) 'A Comparative Study Of Smartphone Addiction Drivers ' Effect On Work', The Journal of Applied Business Research, vol. 32, no. 2, pp. 507-516.

[2] Kwon, M., Lee, Joon-Yeop., Won, Wang-Yon., et al. (2013) 'Development and Validation of a Smartphone Addiction Scale (SAS)', PLoS ONE, vol. 8, no. 2.

[3] Park, J., Kim, K., Kim, N., et al. (2015) 'A comparison of cervical flexion, pain, and clinical depression in frequency of Smartphone use', International Journal of Bio-Science and Bio-Technology, vol. 7, no. 3, pp. 183-190.

[4] Samara, D. (2007) 'Nyeri muskuloskeletal pada leher pekerja dengan posisi pekerjaan yang statis', Neck musculoskletal among workers with static position, vol. 26, no. 3, pp. 137-142.

[5] Siivola, S. M., Levoska, S., Tervonen, O., et al. (2002) 'MRI changes of cervical spine in asymptomatic and symptomatic young adults', European Spine Journal, vol. 11, no. 4, pp. 358-363.

[6] Ariëns, G. A. M., Bongers, P.M., Douwes, M., Miedema., et al. (2001) 'Are neck flexion, neck rotation, and sitting at work risk factors for neck pain? Results of a prospective cohort study', Occupational and Environmental Medicine, vol. 58, no. 3, pp. 200-207.

[7] Prayoga, R.C. 2014. Penatalaksanaan Fisioterapi Pada Cervical Syndrome EC Spondylosis
C3-6 Di RSUD DR. Moewardi (Doctoral dissertation, Universitas Muhammadiyah Surakarta).

[8] Kim, H-J. dan Kim, J-S. (2015) 'The relationship between smartphone use and subjective musculoskeletal symptoms and university students', Journal of Physical Therapy Science, vol. 27, no. 3, pp. 575-579.

[9] Dahlan Sopiyudin M. 2010, Besar Sampel dan Cara Pengambilan Sampel dalam Penelitian Kedokteran dan Kesehatan edisi 3, Jakarta, Salemba Medika.

[10] Tarwaka, Bakri S. H. A. dan Sudiajeng L. 2004, Ergonomi untuk Keselamatan, Kesehatan Kerja dan Produktivitas. UNIBA PRESS, Surakarta.

[11] Motimath B. dan Ahammed N. (2017) '4(3): 207-211 Comparative study on effectiveness of trigger point release versus cervical mobilization in chess players with mechanical neck pain', 207 International Journal of Physical Education, Sports and Health, vol. 4, no. 3, pp. 207-211.

[12] Ahmed, T. (2012) 'Efficacy on Myofascial Release Technique Among The Neck Pain Patient', pp. 2005-2006.

[13] Neupane S., Ali U. T. I. dan A. Mathew. (2017) 'Text Neck Syndrome - Systematic Review', Imperial Journal of Interdisciplinary Research, vol. 3, no. 7, pp. 141-148.

[14] Wijayati, E. W. (2019) 'Risiko Postur Kerja Terhadap Keluhan Subyektif Nyeri Leher Pada Pekerja Industri Kerajinan Kulit', Jurnal Jumantik, 5(1), pp. 56-64. doi: 10.1017/CBO9781107415324.004

[15] Belayana, I. B. G. B., Darmadi, I. G. W. dan Mahayana, I. M. B. (2014) 
'Hubungan Faktor Waktu Kerja, Waktu Istirahat dan Sikap Kerja terhadap Keluhan Nyeri Tengkuk pada Pengerajin Ukiran Kayu', Jurnal Kesehatan Lingkungan, Volume 4(No. 1), pp. 6-15. 